\title{
EFFECTS OF SELECTED HERBICIDES AND PLANT HORMONES ON PROTOTHECA WICKERHAMII
}

\author{
Penelope A. Henning and R. E. Lee \\ Department of Botany and Microbiology, Witwatersrand University, Johannesburg, \\ South Africa 2001
}

PROTOTHECA is most probably a colourless derivative of a green alga such as Chlorella (Davies, Spencer and Wakelin, 1964; El-Ani, 1967; Migaki, Garner and Imes, 1969). The organism lacks chloroplasts and pyrenoids and has adopted a heterotrophic mode of nutrition (Emmons, Binford and Utz, 1970). It is the cause of the infectious disease protothecosis in mammals (Davies et al., 1964; Klintworth, Fetter and Nielsen, 1968; Frank et al., 1969; van Kruiningen, Garner and Schiefer, 1969; Migaki et al., 1969; Povey et al., 1969; van Kruiningen, 1970). In dogs, abscesses are produced in the viscera with some spread to local lymph nodes (Povey et al., 1969). The disease in cows produces a type of mastitis (Frank et al., 1969; Migaki et al., 1969). In man, protothecosis causes lesions in the skin, but spread to the lymph nodes has been reported (Davies et al., 1964; Davies and Wilkinson, 1967; Klintworth et al., 1968).

To date there is no known cure for protothecosis. Treatment in vitro such as irradiation, cytotoxic agents and antiprotozoal drugs show little apparent effect on the organism (Davies and Wilkinson, 1967). Furthermore, this pathogen does not respond to fungal or bacterial antibiotics administered to human patients (Davies et al., 1964; Klintworth et al., 1968; Mars et al., 1971).

The use of herbicides and plant-growth regulators in the control of undesirable plants has increased in recent years. According to the available nitrogen source, it has been found that $P$. zopfii may be inhibited by 3-amino-1,2,4triazole (Casselton, 1964, 1966 and 1967). In the present study the effect of different types of inhibitor on the growth of $\boldsymbol{P}$. wickerhamii was studied in the hope of recognising a substance that might be of value in the control of protothecosis in mammals.

\section{MATERIALS AND METHODS}

The strain of $P$. wickerhamii used was obtained directly from a dermal lesion at the South African Institute for Medical Research (Mars et al., 1971), and was maintained in a nutrientbroth medium consisting of beef extract $0.1 \%(\mathrm{w} / \mathrm{v})$, yeast extract $0.2 \%(\mathrm{w} / \mathrm{v})$, peptone $0.5 \%$ $(\mathrm{w} / \mathrm{v})$ and $10^{-5} \mathrm{M}$ thiamine (Anderson, 1944). The cultures were grown at $32^{\circ} \mathrm{C}$ with a $12-\mathrm{h}$ light-dark cycle of 2000 Lux light (Epel and Krauss, 1966; Emmons et al., 1970). The herbicides selected for study were: maleic hydrazide (MH); 2,4,5-tri-chlorophenoxyacetic acid (2,4,5-T); 2-chloro-4,6-bis(ethylamino)-S-triazine (simazine); sodium chloroauric acid (gold salt), while the plant hormones used were: indolyl-3-acetic acid (IAA); indolyl-3-butyric acid

Received 11 Mar. 1975; accepted 5 June 1975.

J. MED. MICROBIOL.--voL. 9 (1976) 


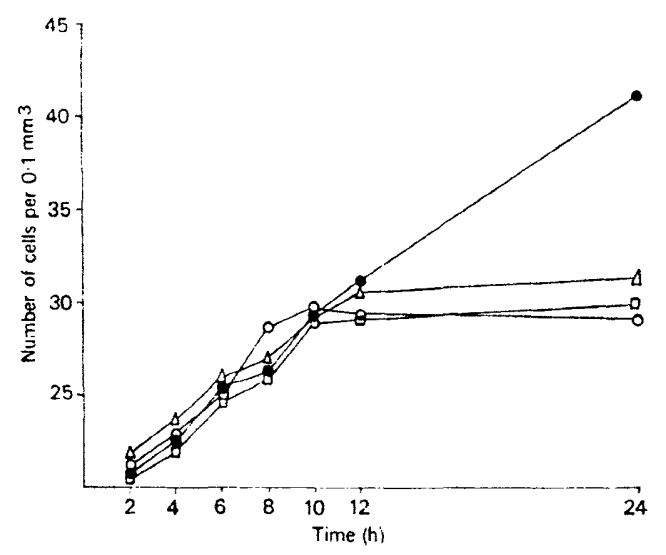

FIG. 1.-Time course curves of Prototheca wickerhamii with different herbicides: $\square-\square=$ IAA. $O-O=$ IBA, $\triangle-\triangle=$ IPA, $-\mathbf{Q}=$ control.

(IBA); indolyl-3-propionic acid (IPA); naphthylacetic acid (NAA); kinetin; gibberellic acid $\left(\mathrm{GA}_{3}\right)$ and coconut milk. All the chemicals were dissolved or diluted in deionised water (Vance and Smith, 1969). They were neutralised with sodium hydroxide, autoclaved and added via sterile syringes to the cell cultures.

Cells of $\boldsymbol{P}$. wickerhamii were grown initially in double-strength nutrient concentration. Addition of stock solution of herbicide to the test-tube gave the selected concentration of herbicide ( $\mu \mathrm{g}$ per $\mathrm{ml}$ ) and the normal nutrient concentration (Vance and Smith, 1969). Control tubes were made up with sterile deionised water. Forty-eight-hour cultures of $\boldsymbol{P}$. wickerhamii were inoculated with herbicides and grown for a further $48 \mathrm{~h}$. The cells were fixed in $2.3 \%$ glutaraldehyde and then counted in a hemacytometer.

\section{RESULTS}

Using time-course curves, we discovered that there was a delay in the absorption or activity (or both) of the inhibitory chemicals (fig. 1). This delay $(d)$ was used in a formula compounded to calculate the percentage inhibition of P. wickerhamii:

$$
\text { percentage inhibition }=\frac{(\mathrm{C} 96-\mathrm{C} 48+d)-(T-\mathrm{C} 48+d)}{(\mathrm{C} 96-\mathrm{C} 48+d)} \times \frac{100}{1}
$$

where $T=$ number of herbicide-treated cells present at $96 \mathrm{~h}, \mathrm{C} 96=$ number of cells present in the control at $96 \mathrm{~h}$, and $\mathrm{C} 48+d=$ number of cells determined from the control after $48 \mathrm{~h}$ plus the delay $(d)$.

Fig. 2 shows the results of experiments with herbicides in the concentration range $100-1000 \mu \mathrm{g}$ per $\mathrm{ml}$. The percentage inhibition with kinetin, which could be used only in the range $10-100 \mu \mathrm{g}$ per $\mathrm{ml}$ because of its insolubility, and with coconut milk (percentage $v / v$ ) is shown in fig. 3 . Fig. 3 also shows the trend of inhibition obtained with IAA, IBA and IPA at lower concentrations. Concentrations of MH, 2,4,5-T, NAA, GA 3 and simazine of $2000 \mu \mathrm{g}$ per $\mathrm{ml}$ and $4000 \mu \mathrm{g}$ per $\mathrm{ml}$ were also used to treat the cells. 


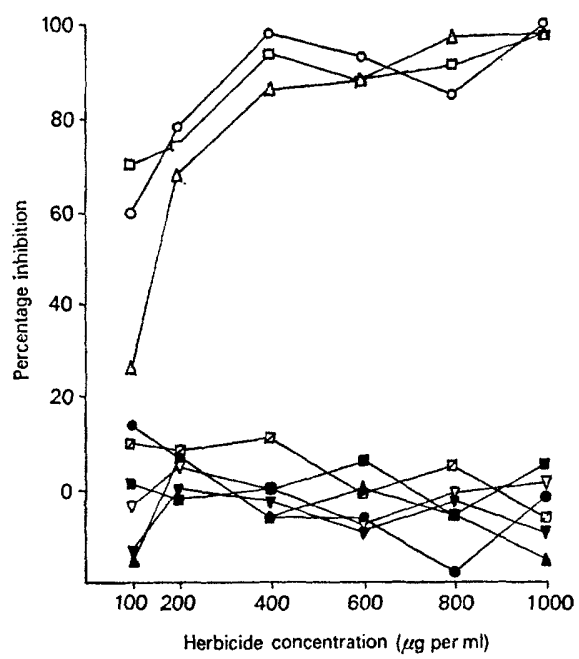

Fig. 2.-Percentage inhibition of $\boldsymbol{P}$. wickerhamii with herbicides at concentrations of 100-1000 $\mu \mathrm{g} / \mathrm{ml}: \square-\square=$ IAA, $\bigcirc-O=$ IBA, $\triangle \triangle \triangle=$ IPA, $\square-\nabla=M H$, $0-\mathrm{NAA}, \mathbf{D - D}=\mathrm{GA}_{3}, \Delta-\mathbf{A}=$ 2,4,5-T, $\square-\square=$ simazine, $\nabla-\nabla=$ gold salt.

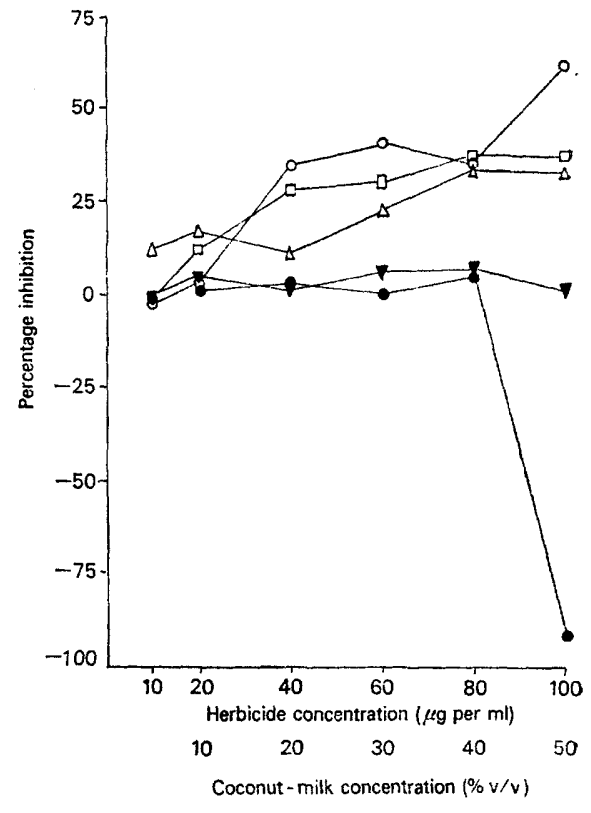

FIG. 3.-Percentage inhibition of $\boldsymbol{P}$. wickerhamii with herbicides at concentrations of 10-100 $\mu \mathrm{g} / \mathrm{ml}: \square-\square=\mathrm{IAA}, \mathrm{O}-\mathrm{O}=$ IBA, $\triangle-\triangle=$ IPA, $\nabla-\nabla=$ kinetin, - coconut milk.

Time-course studies (fig. 1) indicated a levelling off in the increase in cell number after incubation for $10 \mathrm{~h}$ with the inhibitory herbicides. Fig. 2 shows that $\mathrm{MH}, \mathrm{NAA}, 2,4,5-\mathrm{T}$, simazine, gold salt and $\mathrm{GA}_{3}$ did not affect growth. IAA, IBA and IPA inhibited cell growth with maximum effect at $400 \mu \mathrm{g}$ per ml (fig. 2). Coconut milk caused stimulation of growth at the $50 \%(\mathrm{v} / \mathrm{v})$ level, while kinetin had no effect (fig. 3). IAA, IBA and IPA, studied at the lower concentrations, affected cell growth at $60 \mu \mathrm{g}$ per ml, the effect being accentuated with further increase in concentration (fig. 2). The general effect of these three chemicals was a steady increase in inhibition of $P$. wickerhamii from $60 \mu \mathrm{g}$ per $\mathrm{ml}$ to a maximum at $400 \mu \mathrm{g}$ per $\mathrm{ml}$. None of the other chemicals, at the higher concentrations used, produced any effects.

\section{Discussion}

Vance and Smith (1969) were unable to inhibit Chlorella pyrenoidosa growth with 2,4,5-T and simazine at a concentration of $1000 \mu \mathrm{g}$ per $\mathrm{ml}$.

It is known that IAA is present in human urine, and is a normal metabolic product of tryptophan (Anderson, Shimkin and Leake, 1936; Armstrong and Robinson, 1954; Jepson, 1956). Anderson et al. (1936) found the LD50 in 
mice given intraperitoneal injections of IAA to be $25 \mathrm{mg}$ per $\mathrm{kg}$, while the LD50 of IBA and IPA was $100 \mathrm{mg}$ per $\mathrm{kg}$. The lower additional requirement of IAA to attain the LD50 concentration may be accounted for by the presence of IAA in mammalian tissues as a product from tryptophan.

Detailed studies of the IAA concentration in human tissues are necessary before it can be ascertained whether cutaneous application of IAA, IBA or IPA will prove effective in the treatment of protothecosis. It is therefore suggested that the use of these compounds to cure this disease merits further investigation.

\section{SUMmary}

Prototheca wickerhamii was treated in vitro with 11 different herbicides and plant hormones. Growth was inhibited by indolyl-3-acetic acid, indolyl-3butyric acid and indolyl-3-propionic acid at $400 \mu \mathrm{g}$ per ml. Coconut milk was stimulatory.

The authors would like to thank Dr A. R. Rabson of the South African Institute for Medical Research for supplying the culture, We are grateful to Professor C. F. Cresswell for provision of facilities for this work.

\section{REFERENCES}

Anderson, E. H. 1944. Nature of the growth factor for the colourless alga Prototheca zopfii. J. gen. Physiol., 28, 287.

Anderson, H. H., Shimkin, M. B. And Leake, C. D. 1936. Acute intraperitoneal toxicity of some plant growth substances for mice. Proc. Soc. exp. Biol. Med., 34, 138.

ARmstrong, M. D. AND Robinson, K. S. 1954. On the excretion of indole derivatives in phenylketonuria. Archs Biochem. Biophys., 52, 287.

Casselton, P. J. 1964. Reversal by histidine of the inhibition of Prototheca growth due to 3-amino-1,2,4-triazole. Nature, Lond., 204, 93.

Casselton, P. J. 1966. Further observations on the inhibition of Prototheca zopfii growth by 3-amino-1,2,4-triazole. Physiol. Plant. 19, 411.

Casselton, P. J. 1967. Influence of the nitrogen source on the adenine reversal of 3-amino-1,2,4-triazole inhibition of Prototheca zopfii growth. Can. J. Microbiol., 13, 1564.

Davies, R. R., Spencer, H. and Wakelin, P. O. 1964. A case of human protothecosis. Trans. R. Soc. trop. Med. Hyg., 58, 448.

Davies, R. R. AND Wilkinson, J. L. 1967. Human protothecosis: supplementary studies. Ann. trop. Med. Parasit., 61, 112.

EL-ANI, A. S. 1967. Life cycle and variation of Prototheca wickerhamii. Science, N.Y., 156, 1501.

Emmons, C. W., Binford, C. H. And Utz, J. P. 1970. Medical mycology, 2nd ed., Philadelphia, p. 457.

Epel, B. AND Krauss, R. W. 1966. The inhibitory effect of light on growth of Prototheca zopfii Krüger. Biochim. biophys. Acta, 120, 73.

Frank, N., Ferguson, L. C., Cross, R. F. and Redman, D. R. 1969. Prototheca, a cause of bovine mastitis. Am. J. vet. Res., 30, 1785.

JEPSON, J. B. 1956. Indolylacetyl-glutamine and other indole metabolites in Hartnup disease. Biochem. J., 64, 14P.

Klintworth, G. K., Fetter, B. F. and Nielsen, H. S. 1968. Protothecosis, an algal infection: report of a case in man. J. med. Microbiol., 1, 211. 
Kruiningen, H. J. van 1970. Protothecal enterocolitis in a dog. J. Am. vet. med. Ass., $157,56$.

Kruiningen, H. J. van, Garner, F. M. And Schiefer, B. 1969. Protothecosis in a dog. Pathologia vet., 6, 348.

Mars, P. W., Rabson, A. R., RipPey, J. J. AND Ajello, L. 1971. Cutaneous protothecosis. Br.J. Derm., 85, suppl. 7, 76.

Migaki, G., Garner, F. M. AND Imes, G. D. 1969. Bovine protothecosis. A report of three cases. Pathologia vet., 6, 444.

Povey, R. C., Austwick, P. K. C., Pearson, H. and Smith, K. C. 1969. A case of prothecosis in a dog. Pathologia vet., 6, 396.

VANCE, B. D. AND SMITH, D. L. 1969. Effects of five herbicides on three green algae. Tex. J. Sci., 20, 329. 